\title{
Keloid heterograft in the hamster (Mesocricetus auratus) cheek pouch ${ }^{1}$
}

\author{
Heteroenxerto de quelóide na bolsa jugal do \\ hamster (Mesocricetus auratus)
}

\author{
Bernardo Hochman², Flaviane Cássia Vilas Bôas ${ }^{3}$, Mario Mariano ${ }^{4}$, Lydia Masako Ferreira 5 \\ 1. Part of Master thesis presented to São Paulo Federal University-Paulista Medical School (UNIFESP-EPM), in 2002, in Plastic Surgery \\ Post-Graduation Program.Work performed in the Laboratory of Immunology of Department of Parasitology, Microbiology, and \\ Immunology - UNIFESP-EPM. \\ 2. Master of Plastic Surgery - Post-Graduation Program - UNIFESP-EPM. \\ 3. MD Resident Department of Surgery - UNIFESP-EPM. \\ 4. Full Professor of Biomedical Sciences of the Immunology Department of São Paulo University (USP), Full Professor of the Pathology \\ Department of Veterinary Medicine and Zootechnology of USP. Professor of Immunology of the UNIFESP-EPM. \\ 5. Full Professor and Head of the Discipline and Post-Graduation Program of Plastic Surgery - UNIFESP-EPM
}

\begin{abstract}
Purpose: To study the integration of keloid heterograft in hamster (Mesocricetus auratus) cheek pouch. Methods: The sample is formed by 18 male hamsters, heterogenic ones, aged between 10 and 14 weeks. Keloid fragments were obtained from keloid scars of the breast region of adult female mulatto patient. Each hamster received keloid fragments into both of its pouches, in a total of 36 grafted fragments. Animals were distributed into 6 groups for having their grafts assessed in the days 5, 12, 21, 42, 84, and 168. A macroscopic assessment is performed by comparing the pouch containing the grafted fragment, at each time point, with the same pouch in the immediate post surgical moment through a comparison of standardized photographs. Under microscope, the presence of blood vases is considered within the conjunctive tissue of the grafted fragment, as a criterion of its integration. Other events, as keratin secretion, the presence of cellular infiltrated, epithelium and keloid collagen fibers aspects are also analyzed. Results: Macroscopy reveals intensive vascularization of the pouch up to 12 days from the transplantation and the presence of constant dark brown pigmentation on the grafted keloid fragments. In microscopy, the integration of keloid fragments is considered by the presence of blood capillary vases within conjunctive tissue. The presence of intensive cellular inflammatory type infiltrated up to 12 days is also observed, as well as the remaining of keloid epithelium up to 21 days, and the appearing of melanocytes from the day 42 . Conclusion: Hamster cheek pouch represents, a priori, an experimental model for the investigation of keloid.
\end{abstract}

Key words: Mesocricetus. Transplantation, heterologous. Skin transplantation. Keloid.

\section{RESUMO}

Objetivo: Investigar a integração do transplante heterólogo de quelóide na bolsa jugal do hamster (Mesocricetus auratus). Métodos: A amostragem consiste de 18 hamsters machos, heterogênicos, com 10 a 14 semanas de idade. Fragmentos de quelóide foram obtidos de cicatrizes queloidianas da região mamária de paciente adulta parda. Cada hamster foi enxertado em ambas as bolsas com fragmentos de quelóide, totalizando 36 fragmentos enxertados. Os animais foram distribuídos em 6 grupos para exame dos fragmentos enxertados, com 5, 12, 21, 42, 84 e 168 dias. Uma avaliação macroscópica é realizada comparando a bolsa contendo o fragmento enxertado em cada período com a mesma bolsa no pós-operatório imediato, mediante a comparação de fotografias padronizadas. À microscopia, considera-se a presença de vasos sangüíneos no tecido conjuntivo do fragmento enxertado como critério de integração do mesmo. Outros eventos, como secreção de queratina, presença de infiltrados celulares e aspecto do epitélio e das fibras colágenas do quelóide, também são observados. Resultados: A macroscopia revela intensa vascularização na bolsa até 12 dias de enxertia, e a presença constante de pigmentação castanho-escura nos fragmentos de quelóide enxertados. Na microscopia constata-se a integração dos fragmentos de quelóide pela presença de capilares sangüíneos no tecido conjuntivo. Observa-se, também, a presença de intenso infiltrado celular do tipo inflamatório até 12 dias, a permanência do epitélio do quelóide até 21 dias, e o aparecimento de melanócitos a partir de 42 dias. Conclusão: A bolsa jugal do hamster representa, a priori, modelo experimental para investigação do quelóide.

Descritores: Mesocricetus. Transplante heterólogo. Transplante de pele. Quelóide. 


\section{Introduction}

Keloid (from Greek: kelth = tumor + eidoz = shape) is a proliferative healing dysfunction formed by an excessive build up of collagen fibers on the dermis, with a thick and elevated aspect, with a smooth or beveled surface, with color varying from skin color, reddish color, to hyperchromic color. Generally, they are lesions limited to the cutaneous dermis, excepting in rare cases, where it occurs on the corneal epithelium. ${ }^{1}$ Some investigators consider the keloid and the hypertrophic scar as different stages of a same process. ${ }^{2}$ This fact could be reflected by the difficulty which sometimes occurs to clinically differentiate between keloid and hypertrophic scar, where only the histopathological examination may state a diagnosis.

Several factors of risk are known in the keloid development., as tension at the borders of closed wounds by first intention, sutures in regions of thicker skin layer or in areas where a higher concentration of melanin is present, wounds or sutures evolved with infection or healing by second intention. ${ }^{3}$ However, there is not a consensus about the etiology of keloid.

Besides epidemiological and histologic discoveries already registered, and in spite of the understanding so far existing about in vitro mechanisms of the healing biology, and the biochemical action of cytocins, ${ }^{4}$ we still do not know enough about biological actions of these factors on keloid in vivo. This is due to the fact that Homo sapiens is the only one species on which keloid develops. ${ }^{1,5}$ Attempts were performed for provoking keloid in the pig and in the rabbit after BCG injection, aiming to transform them into experimental models for keloid. ${ }^{6}$ However, these scars were not accepted as similar to the both keloid and hypertrophic scars. Thus, the key issue in experimental researches is obtaining a suitable experimental animal model. ${ }^{7,8}$

Most frequently the athymic mouse (nude mouse) is being used for studying the keloid heterologous transplantation. However, in spite of the whole specific bioterium sepsis infrastructure, and laboratory technology for creating, maintaining, and handling these animals, ${ }^{9}$ their own immunodeficiency make them fragile and with high degree of morbidity and mortality, which limit them for some studies. ${ }^{10}$

Hamster (Mesocricetus auratus) is also a small-sized laboratory animal, but it is endowed with normal immune system, and presenting an "Immune Privileged Site” within its jugal pouches sub-epithelium, allowing the integration of both homo- and heterografts. ${ }^{11,12,13,14,15}$ These pouches are diverticular, bilateral, and symmetric structures inside their mouths, with the function of storing and transporting food. The intrinsic mechanism of this privilege of the subepithelium is not fully clear, yet. It is thought that this peculiar characteristic is due to the absence of lymphatic vases in this sub-epithelial region, excepting in the pouch proximal area, where the pouch retractor muscle is inserted. ${ }^{16}$ Therefore, due to the absence of antigenic recognition of homologous and heterologous tissues which are transplanted into the most distal area of this pouch, the drainage satellite lymphonodes (surperficial cervical) would not start the immune response. ${ }^{17,18}$
In the literature, there are studies where the cheek pouch was used to transplant tissues of both benign diseases and malignant neoplasias in order to investigate physiopathology and treatments. ${ }^{19,20}$ In terms of keloid, in spite of the growing trend existing among most of surgical specialties - besides the Plastic Surgery ${ }^{9,21}$ - being also searching after achieving esthetical results, we have scarce literature which is not enough detailed about keloid in the hamster cheek pouch. It was only studied the change of the vascular pattern of this lesion, and simply as a single mention. ${ }^{20}$ The present study purpose is to investigate the integration of keloid heterologous graft into hamster cheek pouch sub-epithelium, as an experimental model.

\section{Methods}

\section{Sampling and experiment design}

Male, exogamic (outbred), aged 10-14 weeks, weighting 90-120 grams hamsters of the species Mesocricetus auratus, also known as Syrian golden hamster, were used. They came from the bioterium of the Center of Experimental Models Development for Medicine and Biology (CEDEME) of the São Paulo Federal University - Paulista Medicine School (UNIFESP-EPM). The laboratory of the Discipline Immunology of UNIFESP-EPM was used for the experiment procedures.

Groups of three animals were kept in suitable plastic cages, with metal superior cover, with adequate feeding and drinking water ad libitum. Six experimental groups with three animals each were formed. Each animal received a graft of keloid fragment in both cheek pouches, in a total of 36 grafted fragments (Figure 1). Animals of the Group A were sacrificed to collect and examining material 5 days after the graft insertion. Group B was analyzed after 12 days, Group C after 21 days, Group D after 42 days, Group E after 84 days and Group $\mathrm{F}$ after 168 days.

Keloid fragments were obtained from three lesions located on the superior-medial quadrants from both breasts of a 27-year old female patient, non-Caucasian, of the ambulatory of the Discipline Plastic Surgery of the Surgery Department of UNIFESP-EPM. These keloids were considered clinically actives when they were resected, this is, the patient should state that the lesions were growing ones, or they would present symptoms as pruritus, and/or pain (Figure 2).$^{22}$ For selecting the patient, her lesions also could not be previously undergone a surgery and relapsed, neither undergone beta-therapy, nor corticosteroid infiltration, nor any other kind of treatment. Moreover, the patient could not have any other metabolic, nor conjunctive, nor auto-immune disease.

Keloid lesions were transported from the surgical room to the experiment laboratory inside a sterile flask containing 0.9\% physiological solution, within a thermo-insulated styropor container (rigid polystyrene) with ice. The timing between material collection and the transplantation in the last experimental animal was under 8 hours. The under keloid remaining subcutaneous tissue resection was performed with curb iris scissors. Fragments for grafting were obtained from the keloid epithelized surface by a $2 \mathrm{~mm}$-diameter 
circular punch. After obtaining all the fragments, they remained immersed in a plastic container containing $0.9 \%$ physiological solution, inside the same thermo-insulated container with ice, until the transplantation moment (Figure 3).

In terms of grafted fragments cataloging, it was standardized that the first fragment code should refer to the studied tissue, in case of letter Q (keloid). The second code refers to Groups A to F. The third code identifies the hamster number, from 1 to 3 , in each group. The fourth code refers to the side of the pouch, using the letter " $\mathrm{d}$ ” for graft performed on the right side and the letter " $\mathrm{e}$ " for the left side.
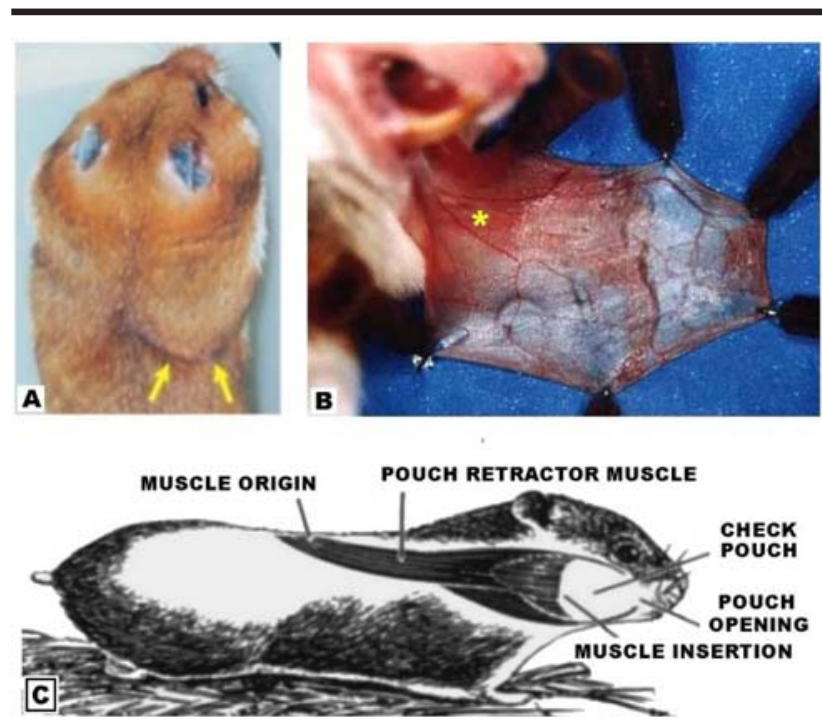

FIGURE 1 - Syrian golden hamster (Mesocricetus auratus). A) Hamster with its right cheek pouch containing food to be transported (arrows). B) Everted and distended cheek pouch showing the pouch retractor muscle $(*)$. C) Scheme of the anatomical disposition of the hamster cheek pouch.

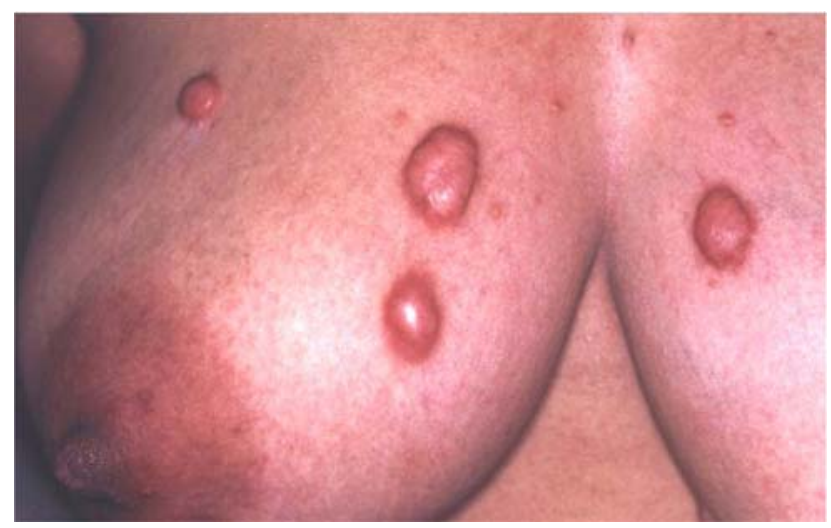

FIGURE 2 - Patient donor of the keloid, with clinically active lesions in the superior-medial quadrant of right and left breasts.
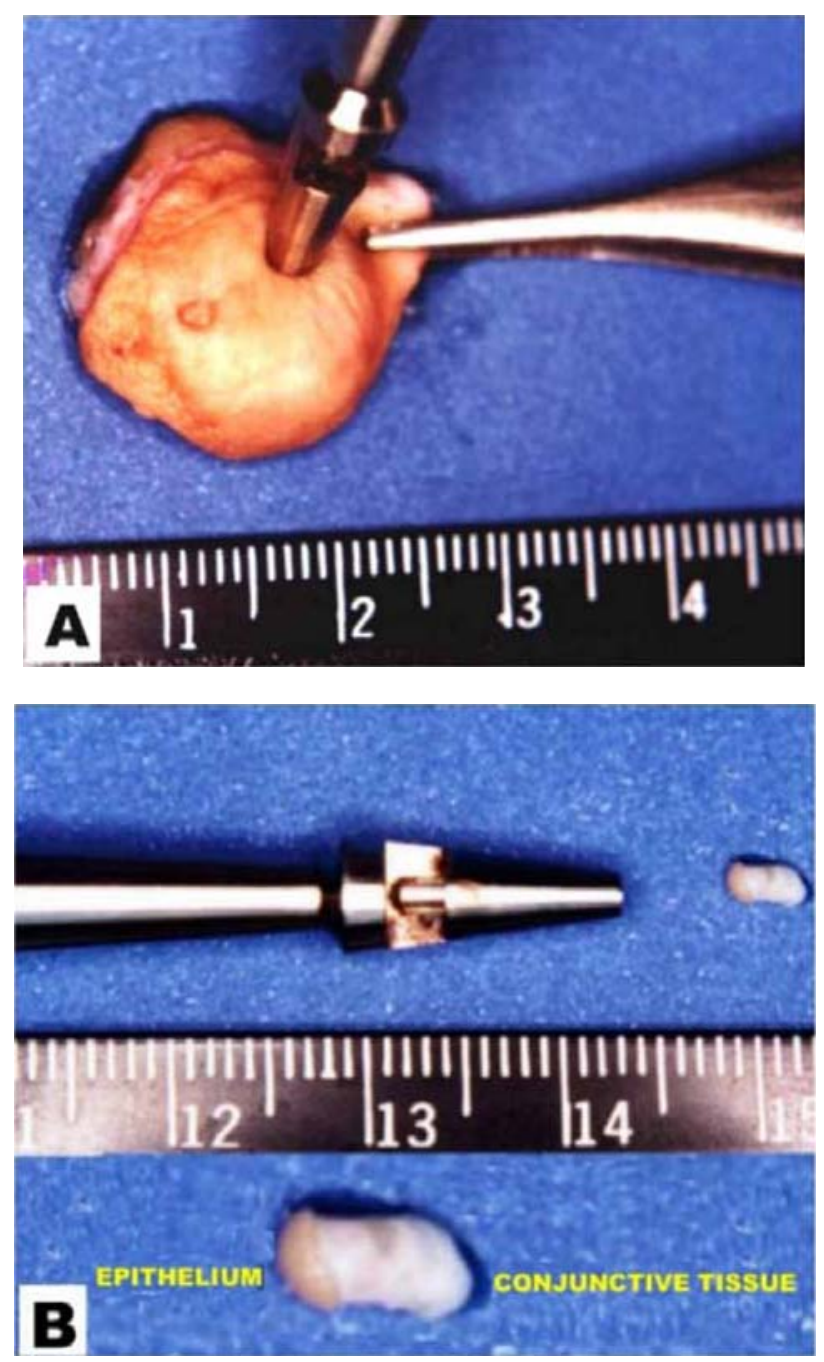

FIGURE 3 - Method for obtaining keloid fragments. A) With a $2 \mathrm{~mm}$ punch, pouch fragments are collected from the epithelized surface, including conjunctive tissue. B) Aspect of the obtained keloid fragment; on the detail we may see both epithelium and conjunctive tissue.

\section{Surgical technique}

The surgeries were performed in animals under general anesthesia by intraperitoneal injection of an association of hydrochloride of 2-(2,6-xilidine)-5,6-dihydro-4H-1,3-tiazine (Rompun ${ }^{\circledR}$ ) in the dose of $0.1 \mathrm{~mL} / \mathrm{kg}$ and ketamine hydrochloride (Francotar ${ }^{\circledR}$ ) in the dose of $0.075 \mathrm{~mL} / \mathrm{kg}$. Surgical procedures did not follow conventional rules on antisepsis and asepsis. Non sterile latex procedure gloves were worn only for protecting the team.

The cheek pouches were washed through the oral cavity with water jets injected with a needle-less plastic syringe, to remove accumulated food residuals or sawdust. Then, each pouch was exteriorized by evertion with two Adson-Brown forceps, and they became distended by fixing with $13 \times 4.5$ needles on a styropor board surface covered by an operative field.

A $5 \mathrm{~mm}$ incision was performed on an avascular area proximal to the first epithelial layer (or "superior layer") of 
the pouch wall, in order to not reach the pouch retractor muscle fibers, which are inserted into its proximal third, to avoid contact with lymphatic vases. With the aid of gentle disection scissors, a rhomboid divulsion as a tunnel was performed in the sub-epithelial conjunctive tissue, up to the most distal point of the pouch. With thin and long pincers, the keloid fragment was inserted between both epithelial layers in the pouch, up to its most distal position (Figure 4). Once the grafted fragment was positioned with the forefinger, the skin fragment was gently compressed between both layers of the pouch wall to allow the natural fixation of the graft by the surrounding areolar conjunctive tissue. The incision on the epithelium was closed by simple bi-digital coaptation of wound borders and, finally, the pouch was invaginated into the oral cavity. ${ }^{14,23}$ Then, after recovered from the general anesthesia, animals were sent to the bioterium.

During the collection of pouches for examination of the grafted keloid fragments, by group, each animal was again anesthetized. Pouches were washed, exteriorized, distended, and fixed at the operative field, following the same procedures performed during the phase of transplantation. After the macroscopic observations, pouches were resected with straight iris scissors at the retractor muscle level. Afterwards, the animals, still under general anesthesia, undergone euthanasia by anesthetic over dose, followed by sulfuric ether inhalation.
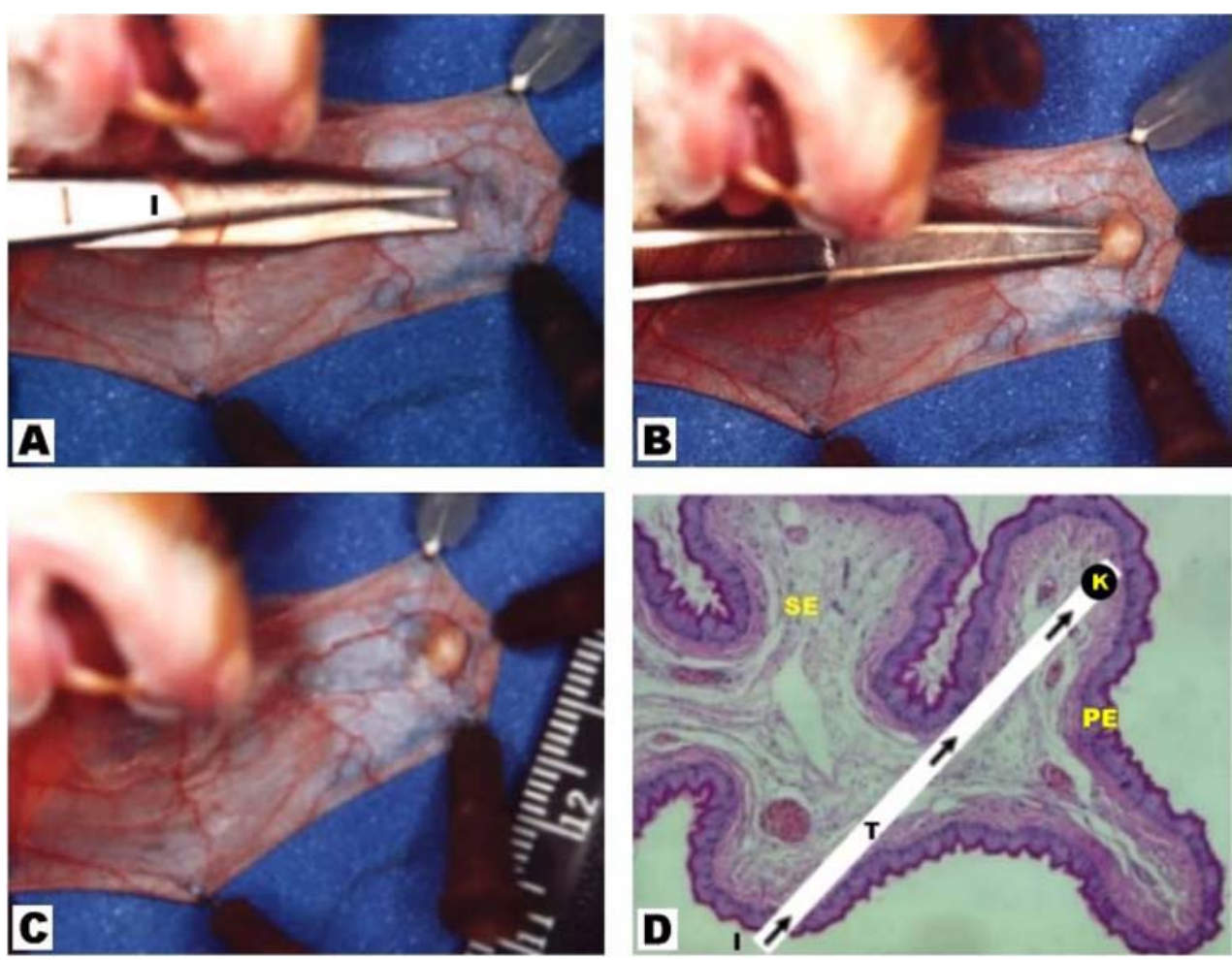

FIGURE 4 - Surgical technique of grafting into hamster cheek pouch. A) Rhomboid subepithelial divulsion in tunnel, towards a pouch distal position. B) Insertion of keloid fragment with long and thin pincers. C) Aspect of the fragment grafted after accommodation by digital compression of adjacent epithelium. D) Microscopic cut of hamster cheek pouch, dyed by hematoxylin-eosine (HE) when seen with 100X magnification, to show schematically the incision (I) of pouch epithelium (PE), the tunnel disection (T) of the sub-epithelium (SE) and the grafted keloid fragment positioning (K).

\section{Macroscopic evaluation of grafted fragments}

Before resecting cheek pouches containing the keloid fragment, with the animal still anesthetized and alive, from the immediate post-operative, before invaginating the pouch to the last group of animals, with 168-day grafts, every graft was observed and photographed. Photographs were obtained with the same equipment and standardized in terms of focal distance, diaphragm opening, distance to operative field, film specification, and flashlight adjustment. Photographs were printed on $10 \times 15 \mathrm{~cm}$ photographic paper.

Besides the observations written on each animal sheet, during the operative act, for each cheek pouch, these photographs obtained in the immediate post-operative were compared with the photographs of grafted fragments, at each operative time point, for analysis. To improve the view of details of the transplants on the pouches and on the grafts, photographs were examined through $4 \mathrm{X}$ magnification lens with coupled fluorescent light source.

According to preliminary observations of the pilot study, issues as (A) "graft presence", (B) "pigmentation presence on the graft”, (C) "graft adjacent vascularization”, and (D) "presence of vascular branch(es) towards the graft" were noted. Issues (A) "graft presence", and (B) 
"pigmentation presence on the graft" were assessed as “absent” (-) or "present” (+). Issues (C) "graft adjacent vascularization”, and (D) "presence of vascular branch(es) towards the graft" were subjectively and semiquantitatively assessed by the investigator by using an arbitrated scale for each of these issues (Table 1). The aspect of the incision of each pouch where the fragment was inserted was also observed, as well as the changes of the pouches, as secretion, suppuration or adherences. ${ }^{14}$

TABLE 1 - Macroscopic criteria for grafts evaluation.

$\begin{array}{ll}\text { (A) } & \text { Presence of the grafted fragment } \\ - & \text { Absent } \\ + & \text { Present } \\ \text { (B) } & \text { Presence of pigmentation on the grafted fragment } \\ - & \text { Absence of pigmentation } \\ + & \text { Presence of pigmentation } \\ \text { (C) } & \text { Adjacent vascularization of grafted fragment } \\ 0 & \text { Absence of adjacent vascularization } \\ + & \text { Vascularization restricted to a small sector around the graft } \\ ++ & \text { Comprehensive vascularization about all the graft periphery } \\ +++ & \text { Vascularization around the whole graft } \\ (D) & \text { Ectasied vascular branch(es) towards the fragment } \\ 0 & \text { Absence of vascular branches towards the graft } \\ + & \text { Presence of } 1 \text { main vascular branch } \\ ++ & \text { Presence of } 2 \text { main vascular branches } \\ +++ & \text { Presence of } 3 \text { main vascular branches }\end{array}$

Legend (C) and (D): Intensity $=0$ to +++ .

Technique for preparation of histologic exams and microscopic parameters

Resected pouches, containing the grafted keloid fragment, were disposed on a small styropor piece with $13 \mathrm{x}$ 4.5 needles (brown). The pouch was transfixed with a $30 \times 8$ (green) needle, in a just-distal position to the grafted fragment, related to the pouch proximal portion. So disposed pouches were fixed into flasks with $12 \%$ formaldehyde, which were wrapped in aluminum foil to prevent the formaldehyde photodegradation.

The preparation of the piece to be sent for examination was standardized in order to direct the histopathology laboratory technician to locate the grafted fragment, which is sometimes hardly visible by the consequent dehydration occurring by the formaldehyde fixing. So, 48 hours after the fixing, a smaller square containing the grafted fragment was cut from the pouch. One of these square sides was sectioned tangent to the grafted keloid, in the position of the hole left by the $30 \times 8$ (green) needle, and on the contralateral side a small triangle was cut to mimic an arrow pointing to the side where the fragment is grafted (Figure 5). These pouches segments, this way obtained, were sent to the histopathology laboratory within tubes with $12 \%$ formaldehyde and also protected from light.

In the laboratory, these pouch segments were dehydrated by crescent alcohol, made diaphanous with xylol, included into paraffin at a 56 to $58{ }^{\circ} \mathrm{C}$ melting point, and undergone microthome adjusted to $5 \mu \mathrm{m}$ thickness and
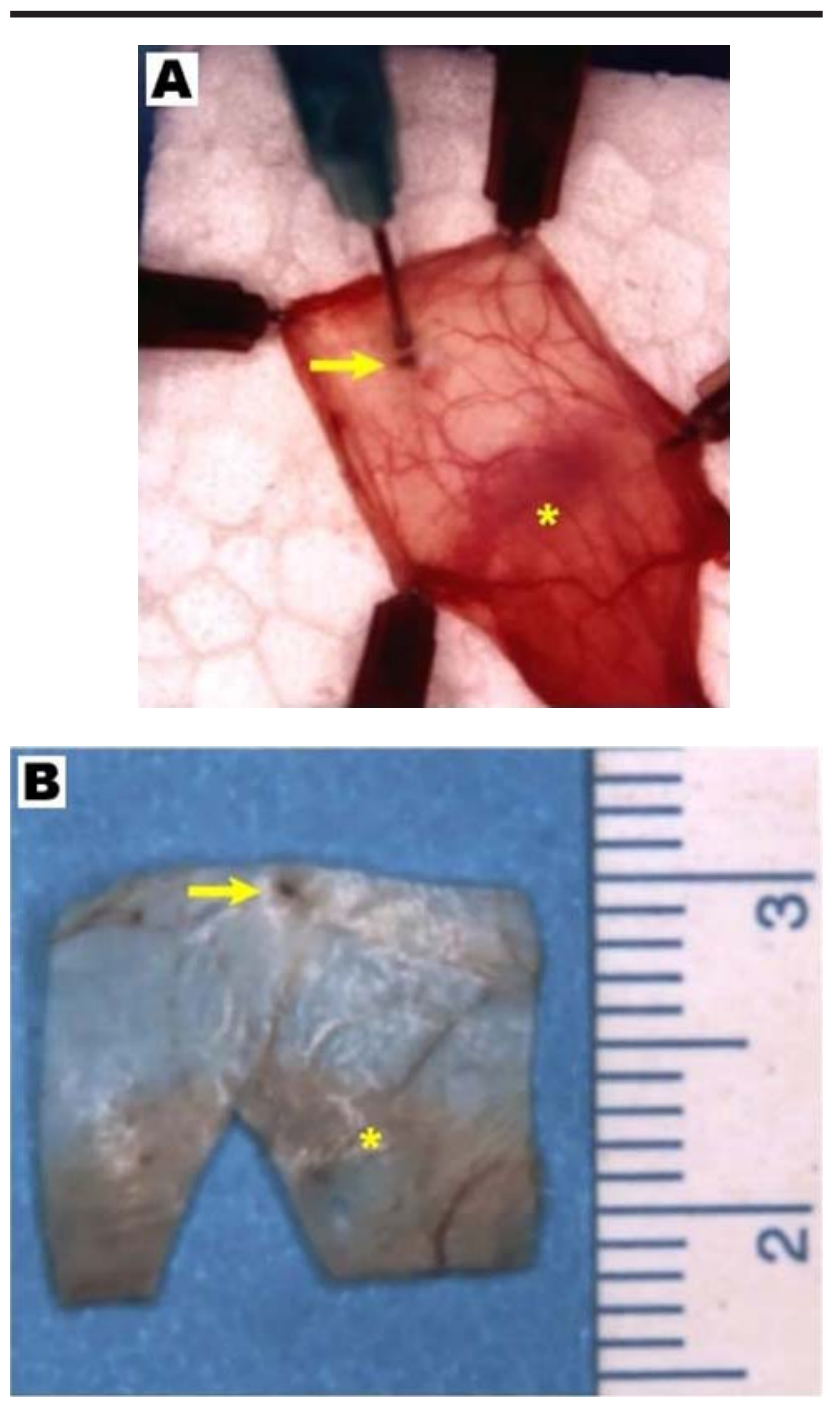

FIGURE 5 - Preparation of cheek pouch for histological exam. A) The resected pouch is distended and fixed on a styropor base, and the graft fragment site (arrow) is marked with a needle, different of the others, in a just-distal point. B) After 2 days in formaldehyde, the pouch is cut as a square, tangent the hole left by the reference needle, in contra-lateral position to the pouch retractor muscle $(*)$. A sector is excised as a triangle on the pouch, at the opposite side of the grafted fragment, to mimic an arrow pointing to the side of the square where it is placed.

the blades were dyed by the Hematoxylin-Eosine (HE) technique.

\section{Microscopic analysis of the grafted fragments}

The histologic investigation was carried out through a light microscope Olympus ${ }^{\circledR}$ model BX60. In this equipment, objectives 20 x $0.50 \mathrm{Ph} 1$ and $40 \times 10.75 \mathrm{Ph} 2$ were used, with a binocular viewer with 10 times magnification, which generated a final magnification 200 and 400 times, respectively. Both linear and sequential scanning was clockwise performed on the microscopic fields. 
As grafted keloid fragments integration parameters the (A) "presence of blood vases" in the peripheral and central regions of the fragment were considered. These vases should contain, as a mandatory issue, hematias in the lumens, and the aspect should not be pletoric; the aim was avoiding to confuse vases with artifacts, or considering vases with their hematias in their early phase, which pertain to the grafted fragment, not to the host, respectively. Blood vases located at the peripheral region limit, or out of it, were considered as a part of the host.

Other issues analyzed in grafted keloid fragments were (B) the "presence of inflammatory infiltrated (represented by mononuclear and/or polymorphonuclear cells)" and (C) “presence of melanocytes”. ${ }^{24}$ It was also observed (D) "presence of epithelium" of grafted fragment and its characteristics, as well as (E) "aspect of collagen” of conjunctive tissue. Issues as (A) “presence of vases”, (B) "presence of inflammatory infiltrated", and (C) "presence of melanocytes" were individually listed as “absent” (-), or as "present" $(+)$.

\section{Results}

\section{Macroscopy}

Animals remained anesthetized in a suitable plan to the surgery, as an average, within 5 minutes after the anesthetic injection. They recovered from the anesthesia, generally, after 30 to 45 minutes after the induction. Procedures (on anesthetized animals) of weighting, pouches washing, exteriorization of both pouches, grafting of fragments into both sides, photograph of the transplanted pouches, and re-introduction of them into the oral cavity lasted, as a mean, 15 minutes for each animal.

Hamsters did not present post-operative morbidity up to the $168^{\text {th }}$ day. Only one death occurred with an animal, in the late post-operative period of 6 weeks (hamster Q-E3). All the cheek pouches remained with transparent epithelium, which allowed to see the grafted keloid fragments. However, the pouches Q-C1d and Q-C3d (21 days) did not contain fragments, nor signs of their transient stay. In the cheek pouch Q-F1e (168 days) the grafted keloid was also not seen, but inflammatory chronic signs, as fibrous retraction were present in the site where the fragment had been inserted.

In the Group A pouches (5 days), all the access incisions to introduce fragments were already closed. The vascularization of the pouch adjacent to the grafted keloid was present in all the grafts of Group A (5 days) and Group B (12 days) pouches, and in two pouches of Group C (21 days). Vascular branch(es) towards the keloid was (were) also present in all the grafted fragments of Groups A (5 days) and B (12 days), in the Q-C1e (21 days) and in the QD3d (42 days) pouches. These branches were present as an ectasia of pre-existing vases on the immediate postoperative photograph, or as an ectasia of vases which, apparently, were not visible in the immediate post-operative period (Figures 6A, 6B). The presence of dark brown pigmentation was observed on every pouches, from the Group D (42 days), excepting on the pouch Q-F1d (168 days) grafting (Figures 6C, 6D). On Figure 7 we may see the summary of macroscopic results of keloid grafted fragments vascularization.

\section{Microscopy}

Of the 31 cheek pouches, which under macroscopy had a perceptible grafted keloid fragment, 2 did not had fragment in the examined blade (Q-B2d and Q-C3d). Of the 29 remaining blades, the fragment was not considered as integrated in 8 pouches ( 4 in the Group A of 5 days, 2 in the Group B of 12 days, and 2 in the Group D of 42 days). In 9 integrated fragments the epithelium was absent, and only the keloid conjunctive tissue was visible (pouches Q-A1d, Q-B3e, Q-C2d, Q-C2c, Q-D3e, Q-E1d, QE1e, Q-E2d, and QF2e).

In the blades of Group A (5 days) there was the presence of dysmorphic epithelium and the conjunctive tissue presented pletoric blood vases and a mixed inflammatory infiltrated “+++" of mono- and polymorphonuclear cells. In Group B (12 days) the epithelium was whole and the conjunctive tissue was vascularized with mixed diffuse inflammatory infiltrated “+++”. In Group C (21 days), the integrity of epithelium with keratin secretion, presence of vases, and reduction of inflammatory infiltrated were seen “+” (Figure 8).

From the Group D (42 days) to the Group F (168 days), melanocytes were identified, and the epithelium presented keratin secretion with cystic formation (Figures 9A, 9B). Keloid epithelium was seen as a whole component in Group D (42 days). In the integrated grafts of the subsequent groups, epithelium dregs or its dysmorphic presentations were observed. Collagen fibers of conjunctive tissue, from the Group D (42 days) thereafter, presented a hyalinized aspect, up to the Group F (168 days), with dysmorphic blood vases and epithelium (Figure 9C).

In Group D (42 days) a blade was seen, in which grafted fragment integration did not occur, including conjunctive tissue, and the area was filled by the fragment substituted for an inflammatory infiltrated (Q-D3d). In the same group, the grafted keloid fragment Q-D2e was not integrated, and the conjunctive tissue, even without vascularization, was hyalinized. On Table 2 and on Figure 10 there are summarized histologic results of grafted keloid fragments. 

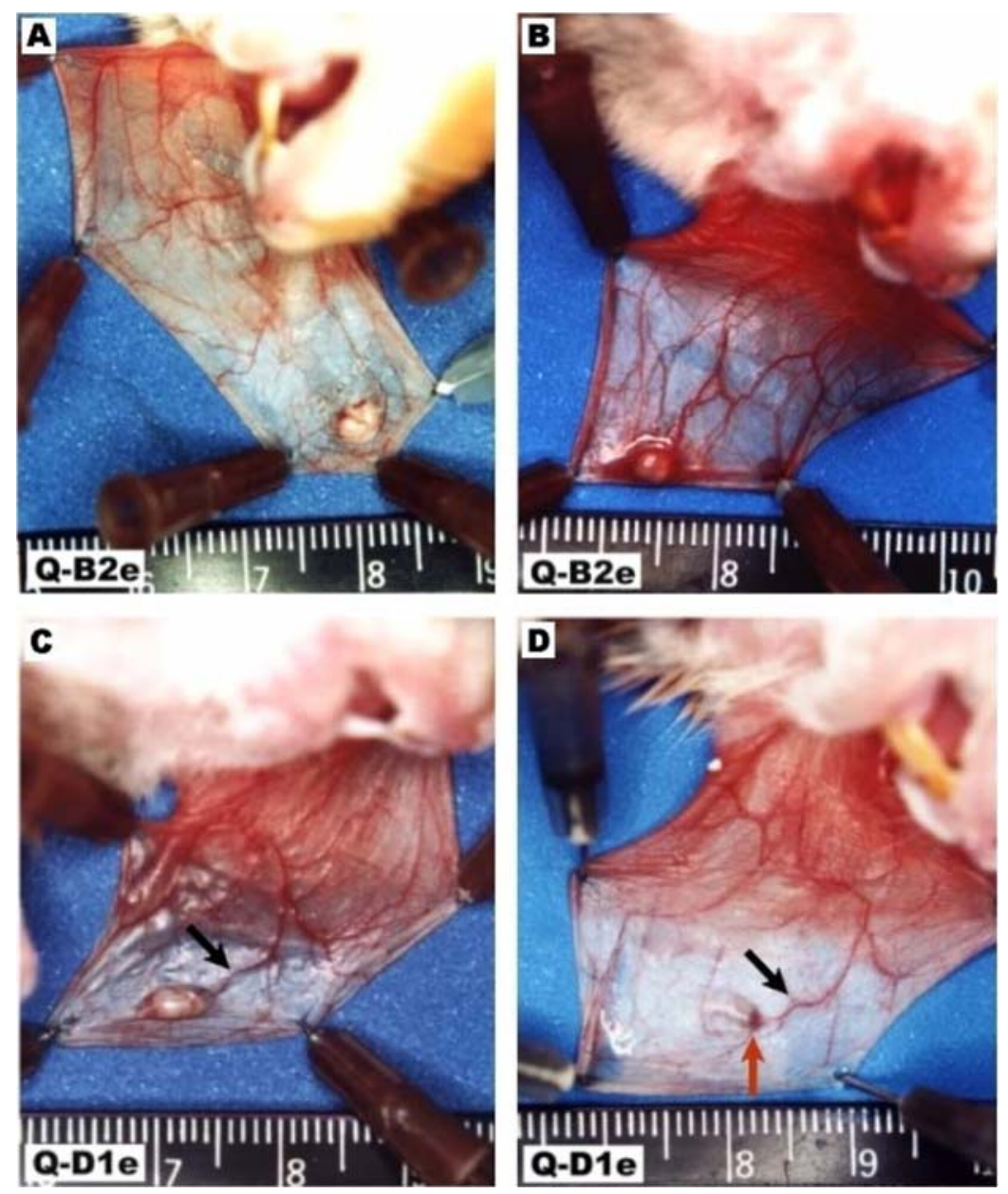

FIGURE 6 - Macroscopic aspect of grafted keloid fragments at 12 and 42 days. A) Immediate post-operative of the fragment Q-B2e. B) At 12 days, intensive vascularization circumjacent to the grafted keloid “+++” (Q-B2e), and presence of new vascular branches towards the graft. C) Immediate post-operative view of the fragment Q-D1e. D) At 42 days, absence of vascularization around the grafted keloid fragment (Q-D1e), and a clear presence of dark-brown pigmentation are observed on the keloid (vertical arrow). The blood vase towards the keloid is a preexisting one (tilted arrow).
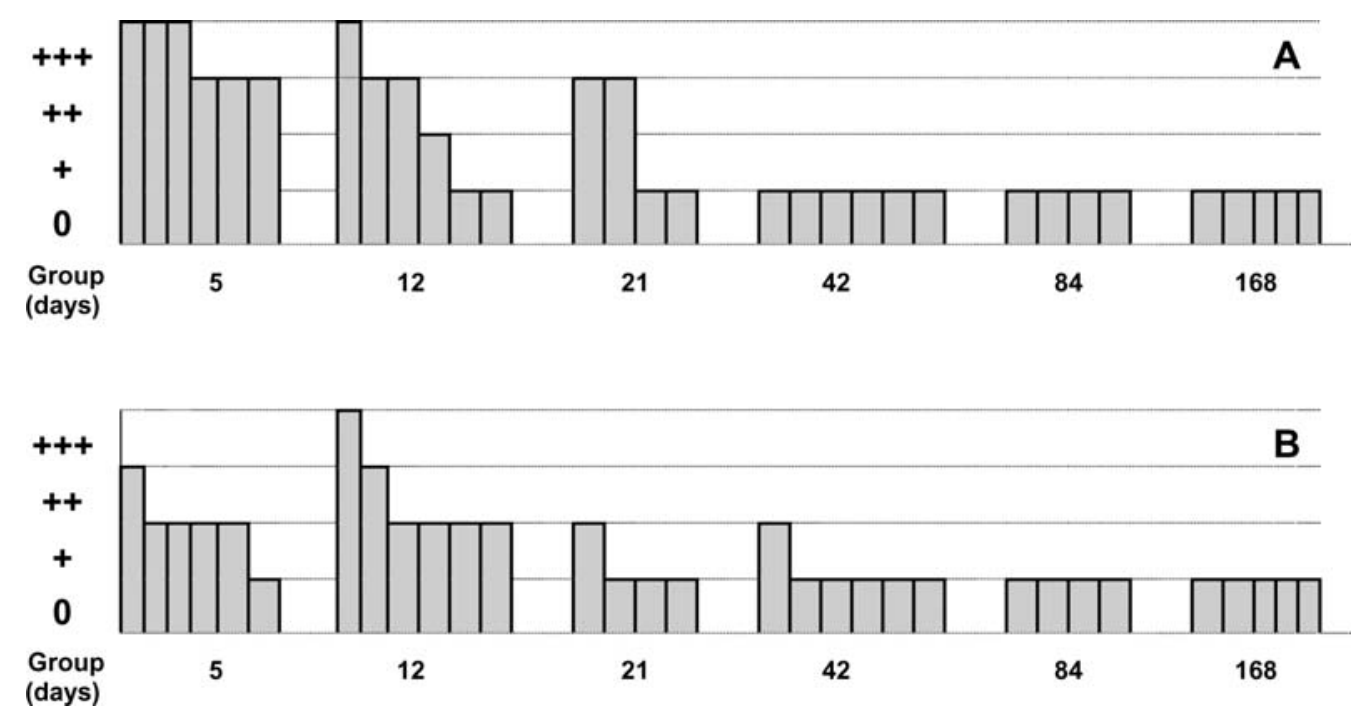

FIGURE 7 - Macroscopic vascular phenomena in keloid grafted fragments. Representation of macroscopic events of the groups, by periods of 5, 12, 21, 42, 84 and 168 days, of the observations related to graft circumjacent vascularization (A) and to the presence of vascular branch towards the graft (B). 

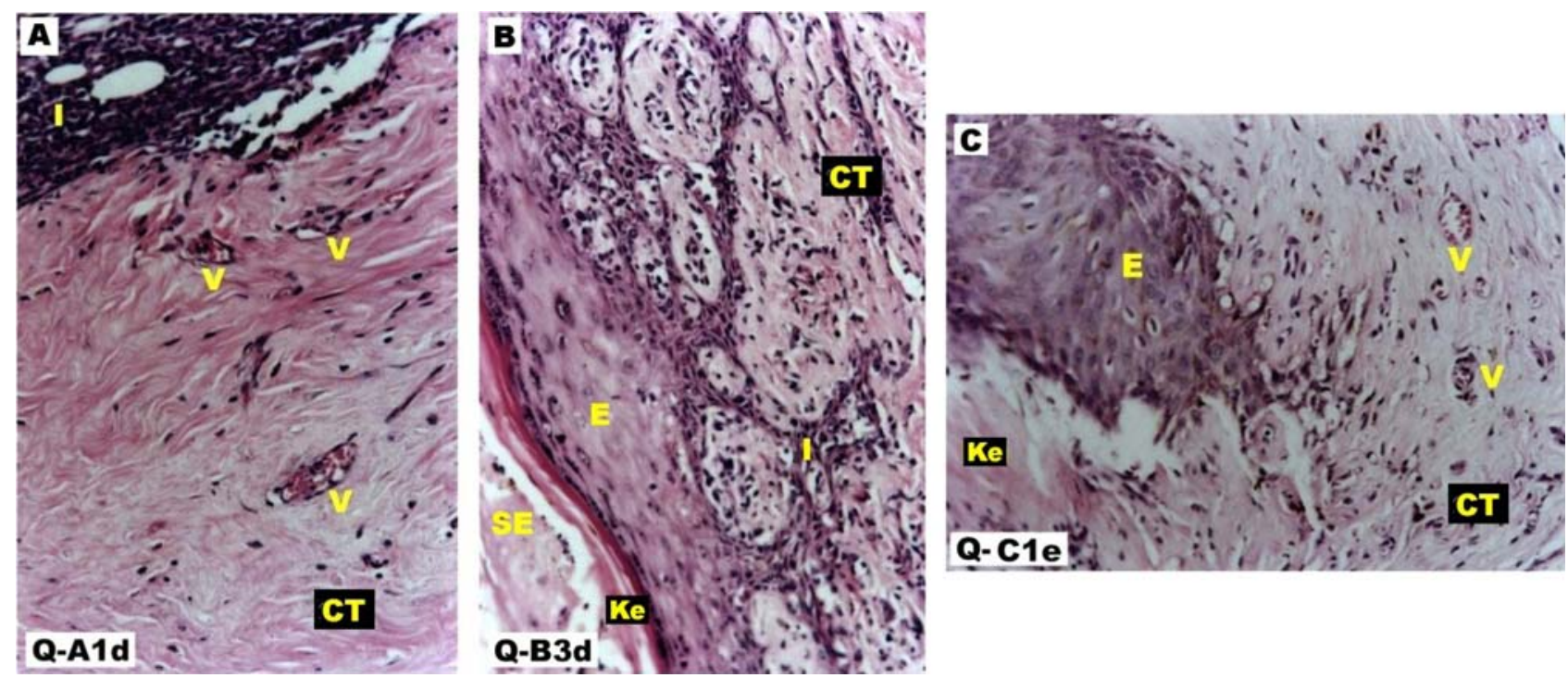

FIGURE 8 - Microscopic aspect of grafted keloid fragments up to 21 days (HE). A) At 5 days, presence of vascularized conjunctive tissue, with intensive mixed inflammatory tissue in the keloid periphery (x200). B) At 12 days, presence of whole epithelium, keratinized, with important inflammatory infiltrated in the peripheral and central regions of keloid (x200). C) At 21 days, presence of whole epithelium with keratin secretion and vascularized conjunctive tissue (x200). [E = Epithelium of the grafted fragment; SE = Sub-epithelium of the cheek pouch; $\mathrm{Ke}=$ Keratin; $\mathrm{V}=$ Blood vase in grafted fragment; I = Inflammatory infiltrated; $\mathrm{CT}=$ Conjunctive tissue .
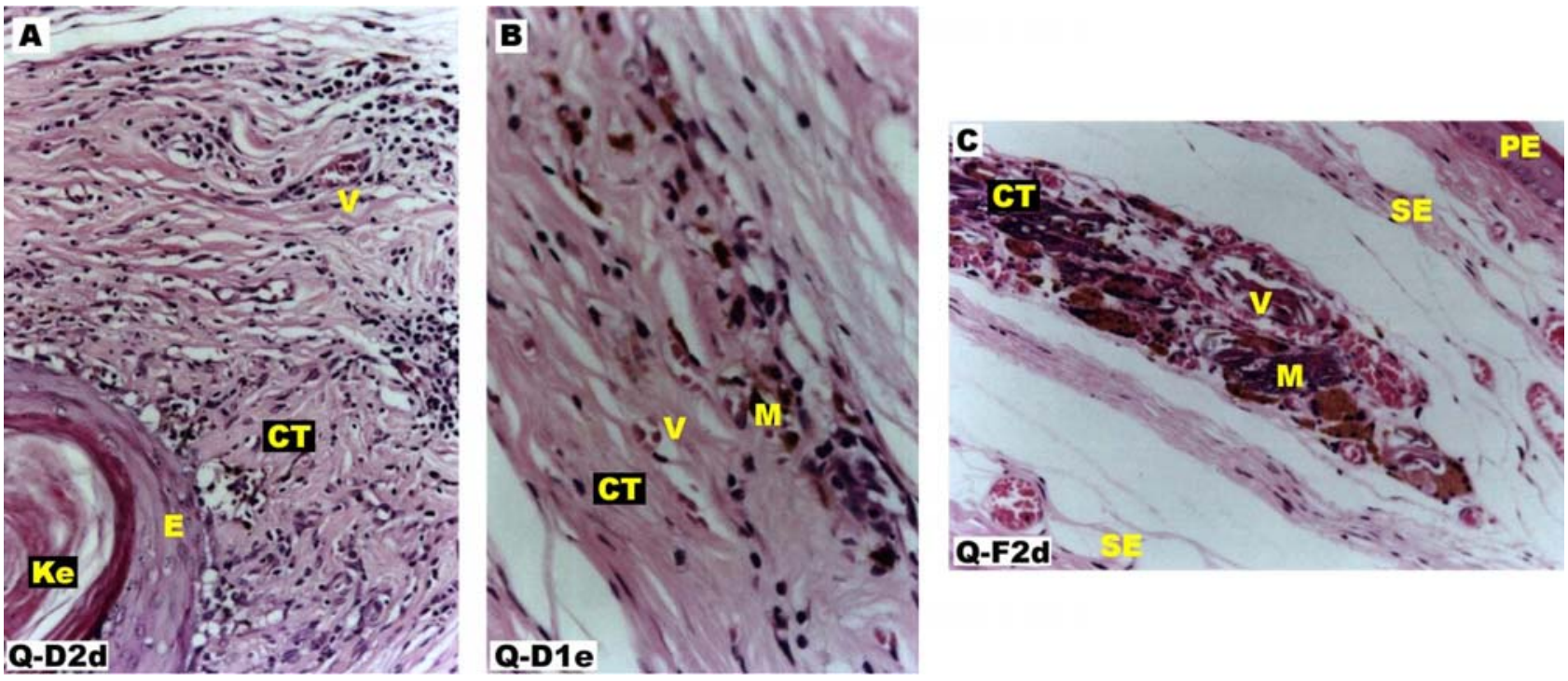

FIGURE 9 - Microscopic fragments of grafted keloid from 42 days to 168 days (HE). A) At 42 days, presence of whole epithelium with keratin cysts (x200). B) At 42 days, besides the presence of only dregs of epithelium, the melanocytes presence may be observed (x400). C) At 168 days, the presence of dysmorphic epithelium with melanocytes and vases in conjunctive tissue may be observed (x400). [PE = Pouch epithelium; E = Epithelium of the grafted fragment; Ke = Keratin; SE = Sub-epithelium of the cheek pouch; V = Blood vase in the grafted fragment; I = Inflammatory infiltrated; $\mathrm{M}$ = melanocytes; $\mathrm{CT}$ = Conjunctive tissue]. 
TABLE 2 - Description of histologic exams on skin grafts.

\begin{tabular}{|c|c|c|c|c|c|c|c|}
\hline $\begin{array}{l}\text { GROUP } \\
\text { (DAYS) }\end{array}$ & FRAGMENT & INTEGRATION & $\begin{array}{l}\text { VASES } \\
\text { (A) }\end{array}$ & $\begin{array}{l}\text { INFLAMMATORY } \\
\text { INFILTRATED } \\
\text { (B) }\end{array}$ & $\begin{array}{l}\text { MELANOCYTES } \\
\text { (C) }\end{array}$ & $\begin{array}{l}\text { EPITHELIUM } \\
\text { KELOID } \\
\text { (D) }\end{array}$ & $\begin{array}{l}\text { COLLAGEN } \\
\text { ASPECT } \\
\text { (E) }\end{array}$ \\
\hline 5 & Qa-A1d & + & + & + & - & Absent & Normal \\
\hline 5 & Qa-A1e & - & - & + & - & Absent & Normal \\
\hline 5 & Qa-A2d & - & - & + & - & Absent & Normal \\
\hline 5 & Qa-A2e & - & - & + & - & Absent & Normal \\
\hline 5 & Qa-A3d & + & + & + & - & Dysmorphic & Normal \\
\hline 5 & Qa-A3e & - & - & + & - & Absent & Normal \\
\hline 12 & Qa-B1d & + & + & + & - & Whole & Normal \\
\hline 12 & Qa-B1e & - & - & + & - & Absent & Normal \\
\hline 12 & Qa-B2d & $\varnothing$ & 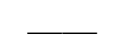 & - & - & - & - \\
\hline 12 & Qa-B2e & - & - & + & - & Absent & Normal \\
\hline 12 & Qa-B3d & + & + & + & - & Whole & Normal \\
\hline 12 & Qa-B3e & + & + & + & - & Absent & Normal \\
\hline 21 & Qa-C1d & - & 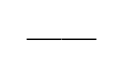 & - & - & - & - \\
\hline 21 & Qa-C1e & + & + & + & + & Whole & Normal \\
\hline 21 & Qa-C2d & + & + & + & - & Absent & Normal \\
\hline 21 & Qa-C2e & + & + & + & - & Absent & Normal \\
\hline 21 & Qa-C3d & - & 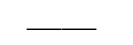 & - & - & - & - \\
\hline 21 & Qa-C3e & + & + & - & + & Dregs & Normal \\
\hline 42 & Qa-D1d & + & + & - & + & Dysmorphic & Hyalinized \\
\hline 42 & Qa-D1e & + & + & - & + & Dregs & Hyalinized \\
\hline 42 & Qa-D2d & + & + & + & + & Whole & Hyalinized \\
\hline 42 & Qa-D2e & - & - & - & - & Absent & Hyalinized \\
\hline 42 & Qa-D3d & - & - & + & - & Absent & Hyalinized \\
\hline 42 & Qa-D3e & + & + & - & - & Absent & Hyalinized \\
\hline 84 & Qa-E1d & + & + & - & - & Absent & Hyalinized \\
\hline 84 & Qa-E1e & + & + & - & - & Absent & Hyalinized \\
\hline 84 & Qa-E2d & + & + & - & - & Absent & Hyalinized \\
\hline 84 & Qa-E2e & + & + & - & + & Dregs & Hyalinized \\
\hline 84 & Qa-E3d & deatt & 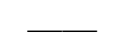 & 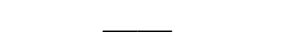 & - & $\longrightarrow$ & 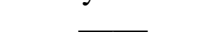 \\
\hline 84 & Qa-E3e & death & 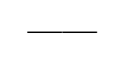 & - & - & $\longrightarrow$ & - \\
\hline 168 & Qa-F1d & $\varnothing$ & - & - & - & 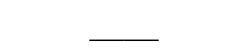 & 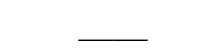 \\
\hline 168 & Qa-F1e & - & 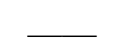 & 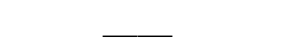 & 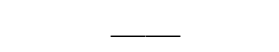 & - & - \\
\hline 168 & Qa-F2d & + & + & - & + & Dysmorphic & Hyalinized \\
\hline 168 & Qa-F2e & + & + & - & - & Absent & Hyalinized \\
\hline 168 & Qa-F3d & + & + & - & - & Absent & Hyalinized \\
\hline 168 & Qa-F3e & + & + & - & + & Dysmorphic & Hyalinized \\
\hline
\end{tabular}

Legend: $\varnothing=$ absence of the grafted fragment on the blade; + = presence; - = absence. 


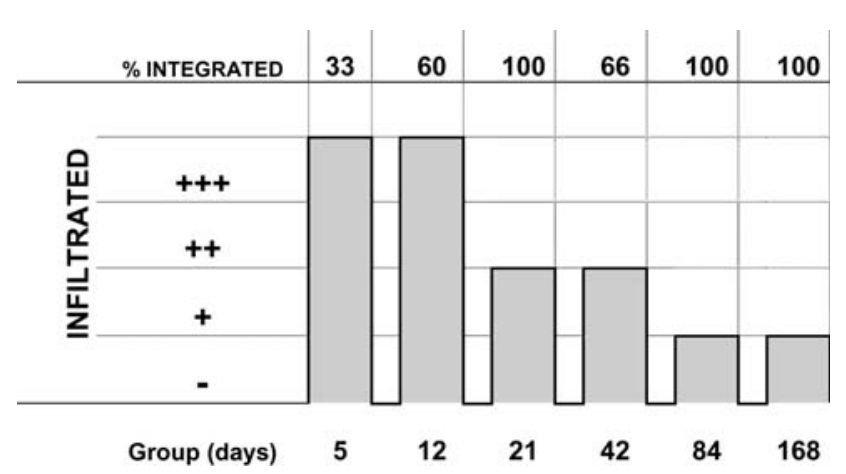

FIGURE 10 - Histologic exam with integration frequency and infiltrated presence, by group, in keloid grafted fragments. Graphic representation of the histologic observations on groups, by periods of 5, 12, 21, 42, 84 and 168 days, referring to the relative percentage of integration and the presence of inflammatory infiltrated.

\section{Discussion}

United States statistics show a prevalence of $1.5 \%$ of persons with keloid, related to the total population. In Africa, statistics show a higher prevalence, reaching $6 \% .{ }^{25}$ In Brazil, keloid is a frequent lesion, in spite of the absence of accurate statistics on this subject. ${ }^{26}$

The bibliographic overview on keloid, over the past 20 years, point out a number of trends in the research lines. In this study, the theme was touched, when the search after an experimental animal model was tried, with higher operational advantages than the available ones, besides being a keloid "carrier", since only the human being may develop this condition. This natural uniqueness, certainly, is avoiding major advances in the investigation of this disturbance.

With these issues in mind, we used the hamster, which a priori, may satisfactorily serve as a model for studying transplantations. This is an animal that survives in natural environment, without being handled, this is, it maintains intact and whole, its immune system, and it has an Immune Privileged Site in the cheek pouch sub-epithelium.

For this study, we opted for male specimens to avoid interference of repetitive estrous cycles of female individuals, during the grafts integration process, as well as in the keloid etiopathology. 5,8,21

Also, we opted for a female, young adult, Afro descendent patient as donor of fragments to be grafted, and these fragments coming from the breast region, because researches indicated a prevalence of keloid among black people compared to Caucasian people, varying from 6:1 to $19: 1^{25}$ and by the observation that $92.3 \%$ of lesions are located on a position superior to the abdomen, and the external region is the most frequent. ${ }^{21}$ On the other side, it was described that, in athymic mice, it should not have an association between the size reduction of the keloid grafted fragment (or hypertrophic scare), with factors such as gender of the donor patient and age of the patient/lesion. ${ }^{7}$
In terms of vascular reaction, in this study was observed, under macroscopy, a more extensive, in the group of 5 days, circumjacent keloid grafts vascularization than the skin grafts into the hamster cheek pouch, in the same post-operative period. ${ }^{14} \mathrm{~A}$ literature report refers the absence of vascular proliferation or vasedilation between the $3^{\text {rd }}$ and $7^{\text {th }}$ days after transplantation, and cites only the appearing of a sinuosity in the blood vases. ${ }^{20}$ However, these data diverge from the ones obtained by the present study. The distinct sinuosity observed by these Authors, at the $3^{\text {rd }}$ or $4^{\text {th }}$ post-operative day, would be a specific vascular response to the transplantation, and would only occur to a distance of $5 \mathrm{~mm}$ around the graft. This type of reaction was already observed around certain kinds of strange materials, as thread of catgut suture, silk, synthetic fibers, and metal implants. ${ }^{27}$ Nevertheless, other works were not found in the literature over keloid graft into the hamster cheek pouch, in order that we may compare in a more detailed way the results we achieved.

The presence of vascular branches towards the grafted fragment, also under macroscopic exam, occurred in the 5day group and, most intensively, in the 12-day group. In both, the presence of vascular branches was more frequent than in heterologous grafts of human skin into the hamster cheek pouch. ${ }^{14}$ This apparent re-vascularization which is more intensive in keloid grafts, would indicate a higher need of vascular arrival of this tissue when compared to skin grafts, mainly in the earliest phases. In the literature, keloid grafts and hypertrophic scare in athymic mouse also present, under macroscopy, a subcutaneous arterial branch towards the fragment, generally alone. ${ }^{7}$

This higher need of vascularization of keloid grafts, compared to the skin ones, may be explained by the fact that in the groups of 5 and 12 days, when the transition between soaking and inoculation occurs, the keloid's intrinsic vases, in contrast with normal capillary of skin, would appear as incompetent. This handicap would result because the keloid tissue is hypoxic, due to the vascular occlusion by an abnormal proliferation of endothelial cells. ${ }^{28}$ As a consequence, in the critical initial phase of the transplant integration, a higher demand for vascular arrival from the receptor bed would occur in the case of keloid, compared to the skin.

The presence of a mixed and not specific inflammatory infiltrated, by mono- and polymorfonuclear cells, was highlighted in the groups of 5 and 12 days, in the grafted keloid fragments. There was an initial perception, in these groups, that most of the grafted fragments would not be integrated, because we thought that the achieved integration rates, by histologic exam, were only $33 \%$ and $60 \%$, respectively. Rates of the groups of 21 and 42 days were $66 \%$, ending in $100 \%$ in the groups of 84 and 168 days. This leukocyte effect was already described in the athymic mouse, where also a diffuse, not specific, cellular infiltrated occurs in the first week after the heterograft of human skin. This cellular infiltration caused that in the early investigations with athymic animals, it was wrongly diagnosed as rejection of the grafted fragment. However, after this initial period of grafting, it was seen that the infiltrated was very decreased and it was proved that the grafts integrated themselves. Therefore, those low initial 
rates of keloid fragments integration, which were reached, did not represent the truth of the facts. Otherwise, if animals of the groups 5 and 12 days, in which the thought was that grafted fragment did not integrate, had been lately sacrificed, the diagnostic could be that the integration actually occurred, in the same ones which were considered as not integrated. The presence of this infiltrated could also be due to an early and incipient reaction to the transplantation, but inefficient due to a functional impairment of lymphocytes. ${ }^{24,27}$

Human skin fragments into the hamster cheek pouch also present not specific inflammatory infiltration during the early phases of grafting, but with less intensity than in keloid. ${ }^{14,23}$ This difference of infiltration could be translated into the fact that skin heterografts into the hamster pouch were presenting higher and earlier integration rates, ${ }^{14}$ besides keloid microvascular occlusive commitment. Since a real phenomenon of immune rejection was not characterized in the hamster cheek pouch sub-epithelium, and the fragments of keloid present a more intensive inflammatory infiltration than the heterologous skin grafts, ${ }^{14}$ this study allows us to suggest that the keloid graft has a more intensive proinflammatory factor than the skin grafts.

From the group of 42 days thereafter, an evident and constant presence of melanocytes in keloid grafted fragments was seen. The attention was attracted by this notorious presence of melanocytes, because this lesion, when in natura, has a negligible amount of this pigment, ${ }^{26}$ and because the hamster does not have melanin, as well as its cheek pouch does not have appendages nor pigmentation. ${ }^{29}$

As a matter of fact, which prevails is the binomial "keloid-melanin absence”. Low pigmented areas with scarce sebaceous glands are rarely keloid sites. Also, it is very rare the occurrence of keloids on the foot sole and hand palm, even in people who are carriers of keloid scares, and in spite of these regions being constantly subjected to abrasion and traumas. ${ }^{(2)}$ Keloid was neither referred as occurring in albino people. ${ }^{5}$

In the literature there is not any citation of this pigment presence in studies where keloid was grafted into athymic mice. Since the present study is original in detailing keloid integration into the hamster cheek pouch, it allowed melanin pigmentation to be by the first time seen, due to the transparence of the pouch epithelium. In athymic mice, the presence of melanocytes was not cited in the studies on keloid grafting, probably because of the previous disepitehelization performed in the grafted fragments, since the grafting was performed inside the subcutaneous tissue of those animals, so preventing the appearing of inclusion cysts. The general mention of these reports was "there was a preservation of the tissue original characteristics" this is, it was implicit that actually there was not presence of melanocytes in the grafted fragments examination, because said cells are practically absent in the in natura keloid. From this study, it is possible to infer, in terms of the presence of melanocytes in the keloid grafting, that the precursor cell, possibly the melanoblast, would be intrinsically present in the grafted keloid and, by any factor or by the presence of any substance in the human being, the change to melanocyte should not occur in the keloid scare. In hamster, however, due to the absence of that factor or substance, the melanoblast could be evidently differenced into melanocyte.

There was a relevant quantity of grafted fragments of keloid with lack of epithelia integrity preservation. From the 21 integrated keloid fragments, in 4 fragments the epithelium remained whole. The epithelium presented under the form of dregs in 3 fragments, dysmorphic in 4 fragments, and absent in 10 fragments. The most probable explanation is that the inclusion of the grafting epithelium did not occurred in the preparation of several histologic blades, but only conjunctive tissue. The ability of the epithelium of grafted tissue, in the hamster cheek pouch, is confirmed by other works in the literature, where epithelized organs and tumors tissues were transplanted, including cutaneous human tissues, and the Authors referred integration and development of many of these tissues, describing preservation of the original histologic architecture. ${ }^{11,19}$

The later integration of grafted with whole epithelium keloid fragments (Q-D2d) reached 42 days, but reached 168 days of survival, with only conjunctive tissue. In this late phase, in spite of the structure of collagen fibers of the grafted fragment being hyalinized, the presence of blood vases in the conjunctive tissue, indicated a cellular still active metabolism of it. On the other hand, not integrated keloid grafted fragments are described, in the results, as having a collagen with normal aspect. This apparent paradox may be explained because it is not vascularized, the structure of collagen fibers in the conjunctive tissue, after being dyed by hematosylin-eosin, presented similar to the conjunctive tissue of the integrated fragments, excepting by the absence of blood vases and a lower cellular density. The visual impression existing in these blades of fragments not integrated (Q-A1e, Q-A2d, Q-A2e, Q-A3e, Q-B1e, Q-B2e, Q-D2e), would be a "fossilization" of the collagen structure. Histologic exams with other specific techniques of dyeing, or by other types of histologic preparation, would be needed to clarify in details this subject.

In face of the results reached in this study, and with the experimental design applied, we may suggest that this model may be used in heterologous keloid grafting, with the maintaining of the epithelium integrity, up to 21 days. To suggest this term, a strict margin of safety was adopted, because the keloid grafted fragment Q-D2d reached 42 days with preservation of its epithelium. When the presence of whole epithelia is not demanded in the analysis of grafted fragments, or if disepithelized fragments are transplanted as it occurs in athymic mice, ${ }^{30}$ the experimental model here described could be used, from the morphologic point of view, for studying keloid transplant for up to 168 days. However, it should be observed that collagen fibers triggered a hyalinization process, from the group of 42 days of grafting, and they show hyalinization from the group of 84 days.

Because of all the peculiarities above described, we may consider hamster as a model which presents several advantages on the athymic mouse or other experimental models, for studying keloid transplantations. Moreover, the hamster would have the advantage of presenting normal immunity and tissue mastocytes with secretor pattern similar to the human being, and therefore it is ideal for studying keloid. Although the athymic mouse has been most widely 
used in studies on integration of keloid heterologous grafts, the hamster, as experimental model, presents other particular characteristics that could be transformed into advantages. As the anatomical location and the immune privilege of cheek pouches of the animal keep independence between them, each pouch may be considered and approached as a subunit of this experimental model. Thus, it is possible grafting into each pouch, tissues from different origins (skin, scares, or organs) and donors (self-, homo-, and heterografts). In this study, for example, it would be viable to graft both skin and keloid in each pouch of the same animal. We may also profit the characteristic that the pouch may receive more than one fragment of the same tissue, and multiply the amount of fragments obtained in a same animal. Moreover, the hamster, since it is not weakened, allows that conditions like feeding, maintaining, and environmental asepsis are the basic and not expensive ones.

In terms of the complication rate in the animals, the results of this study are in line with the ones found in the existing literature. ${ }^{11}$ It was described a post-operative rate of complications inferior than $5 \%$ in the grafting into the hamster cheek pouch, and without following conventional asepsis standards.

A fragment of keloid was absent in the group of 168 days (Q-F1e) under both macro- and microscopy, with signs of chronic inflammation in the grafting site, suggesting degeneration or absorption of the fragment. A late postoperative death also occurred, from unknown cause in the group of 84 days (Q-E3). In 2 hamsters in the group of 21 days (Q-C1d and Q-C3d), in one pouch of each animal, the keloid fragments were not present. Possibly, by technical reasons, the extrusion of these fragments occurred during the post-operative period, by the excessive divulsion of these pouches sub-epithelium during the grafting. The muscle contraction of the pouch the animal performs to empty the contents with food, could be made easy the extrusion. The pioneer characteristic of this study and the discernment of the results encourage the development of this experimental model, in order that in the future more scientific information is obtained about heterologous grafts. Besides the need of improving the insertion of fragments into the pouches, aiming to prevent their extrusion, it is a must to improve the tactic of pouches preparation with fragments for the histologic assessment, in order to include the epithelium systematically also.

In athymic mice, it was already showed that the analysis of the grade of cellular activity of keloid grafted fragments coming from the same donor may significantly vary among the animals. ${ }^{7}$ Similarly, keloid grafted fragments from different donors may also present variations of cellular activity on different athymic mice. In athymic mice, it would exist a gradient of individual sensitivity to keloid grafts from the same donor, as well as an ability of graft-host interaction which is different in each mouse, for keloid fragments coming from different donors. Therefore, this information about athymic mice must be better studied in hamsters. It is also a must to do further studies with a greater number of donors of keloid fragments for this experimental model, with the purpose of enlarging the viable term of 21 days we reached in the present work for obtaining heterologous grafts with preservation of the epithelium.
This study highlighted an aspect which was up today yet not clarified in the available literature. If, as a thesis, there is not immune rejection in the hamster cheek pouch sub-epithelium, why the inflammatory-type infiltrated existing in the keloid grafted fragments is more intensive than the ones of skin ${ }^{14}$ How would be, and how would work this more intensive pro-inflammatory factor on the keloid? The elucidation of this pro-inflammatory factor could bring important subsides to the keloid understanding. Therefore, further investigations with immunologic content have to be performed.

The presence of melanocytes in the grafted keloid fragments, which were found in the present study, open new horizons in searching for the keloid ethiopathogeny. Therefore, the need is clear of investing more in lines of researches on the Melanocyte-Stimulating Hormone (MSH) physiology, on melanocytes, and on melanin metabolism. It is needed to investigate which would be the factor we detected in this study, and which would make unviable the differentiation of melanocytes in keloid into humans, but not when it is grafted into hamsters. From the first scientific description of keloid, by Jean Louis Alibert, in 1806, the Science has performed a number of works trying to resolve this important disturbance of the healing process. The final impression left by this work is very encouraging in view of the possibility that the hamster may be an experimental animal model, perhaps the ideal one, to perform immunobiology studies and, in the present case, searching after elucidating, to effectively prevent and definitely treating the keloid.

\section{Conclusion}

Fragments of keloid grafted into hamster (Mesocricetus auratus) cheek pouch sub-epithelium remained vascularized for 168 days. The graft epithelium may be observed whole for up to 21 days. The results, as a set, allow us to establish the hamster cheek pouch as an experimental model of keloid heterologous grafts investigation.

\section{References}

1. Sullivan STO, Shaughnessy MO. Aetiology and management of hypertrophic scars and keloids. Ann R Coll Surg Engl. 1996;78:168-75.

2. Reis ALN. Principais características das cicatrizes queloideanas. An Bras Dermatol. 1994;69(6):495-7.

3. Rockwell WB, Cohen IK, Ehrlich HP. Keloids and hypertrophic scars: a comprehensive review. Plast Reconstr Surg. 1989;84(5):827-37.

4. Calderon M, Lawrence WT, Banes AJ. Increased proliferation in keloid fibroblasts wounded in vitro. J Surg Res. 1996;61:343-7.

5. Placik OJ, Lewis VL. Immunologic associations of keloids. Surg Gynecol Obstet. 1992;175:185-93.

6. Estrem SA, Domayer M, Bardach J, Cram AE. Implantation of human keloid into athymic mice. Laryngoscope. 1987;97:1214-8.

7. Kischer CW, Pindur J, Shetlar MR, Shetlar MS. Implants of hypertrophic scars and keloids into the nude (athymic) mouse: viability and morphology. J Trauma. 
1989;29(5):672-7.

8. Schierle HP, Scholz D, Lemperle G. Elevated levels of testosterone receptors in keloid tissue: an experimental investigation. Plast Reconstr Surg. 1997;100(2):390-4.

9. Benhaim P, Anthony JP, Ferreira L, Borsanyi JP, Mathes SJ. Use of combination of low-dose cyclosporine and RS-61443 in a rat hindlimb model of composite tissue allotransplantation. Transplantation. 1996;61(4):527-32.

10. Hochman B, Ferreira LM, Vilas Bôas F. Modelo experimental para estúdio de injerto heterólogo de piel total. In: XIII Congreso de la Federación Iberolatinoamericana de Cirugia Plástica; 2000; Lima. Anais. Lima: Sociedad de Cirugía Plástica Reconstructiva y Estética del Peru; 2000. p.281-5.

11. Lemon HM, Lutz BR, Pope R, Parsons L, Handler AH, Patt DI. Survival and growth of human tissues transplanted to hamster cheek pouch. Science. 1952; 115:461-4.

12. Billingham RE, Silvers WK. Syrian hamsters and transplantation immunity. Plast Reconstr Surg. 1964;34(4):329-53.

13. Head JR, Billingham RE. Immunologically privileged sites in transplantation immunology and oncology. Perspec Biol Med. 1985; 29(1):115-31.

14. Hochman B, Ferreira LM, Vilas Bôas FC, Mariano M. Integração do enxerto heterólogo de pele humana no subepitélio da bolsa jugal do hamster (Mesocricetus auratus). Acta Cir Bras. 2003;18(5):415-30.

15. Shepro D, Kula N, Halkett JAE. The role of the cheek pouch in effecting transplantation immunity in the hamster. J Exp Med. 1963;117: 749-54.

16. Goldenberg DM, Steinborn W. Reduced lymphatic drainage from hamster cheek pouch. Proc Soc Exp Bio Med. 1970; 135:724-6.

17. Sinhorini IL, Merusse JLB, Mariano M. The role of lymphatic drainage on the development of BCG-induced granulomas in the hamster. Int Arch Allergy Immunol. 1994;103:166-74.

18. Arruda MSP, Montenegro MR. The hamster cheek pouch: an immunologically privileged site suitable to the study of granulomatous infections. Rev Inst Med Trop Sao Paulo. 1995;7(4):303-9.

19. Williams DE, Evans DMD, Blamey RW. The primary implantation of human tumours to the hamster cheek pouch. Br J Cancer. 1971;25(3):533-7.

20. Wolf JE, Hubler WR. Tumor angiogenic factor and human skin tumors. Arch Dermatol. 1975; 111:321-7.

21. Cosman B, Crikelair GF, Ju DMC, Gaulin JC, Lattes R. The surgical treatment of keloids. Plast Recontr Surg. 1961;27(4):335-58.

22. Shetlar MR, Shetlar CL, Hendricks L, Kischer CW. The use of athymic nude mice for the study of human keloids. Proc Soc Exp Biol Med. 1985;179:549-52.

23. Hochman B, Ferreira LM, Vilas Bôas FC, Mariano M. Investigação do transplante heterólogo de quelóide na bolsa jugal do hamster (Mesocricetus auratus). Acta Cir Bras. 2003;18(4):266-71.

24. Cohen SN. Comparision of autologous and heterologous normal skin grafts in the hamster cheek pouch. Proc Soc Exp Bio Med. 1961; 106:677-80.

25. Dustan HP. Does keloid pathogenesis hold the key to understanding black/white differences in hypertension severity? Hypertension. 1995;26(6):858-61.

26. Canary PCV, Fillipo R, Pinto LHP, Aidar S. Papel da radioterapia no tratamento de quelóides: análise retrospectiva de 267 casos. Rev Bras Cir. 1990;80(5):291-5.

27. Nishioka K, Ryan TJ. The influence of the epidermis and other tissues on blood vessel growth in the hamster cheek pouch. J Invest Dermatol. 1972;58(1):33-45.

28. Kischer CW, Thies AC, Chvapil M. Perivascular myofibroblasts and microvascular occlusion in hypertrophic scars and keloids. Hum Pathol. 1982;13(9):819-24.

29. Haller JA, Billingham RE. Studies of the origin of the vasculature in free skin grafts. Ann Surg. 1967; 166(6):896-01.

30. Shetlar MR, Shetlar CL, Kischer CW, Pindur J. Implants of keloid and hypertrophic scars into the athymic nude mouse: changes in the glycosaminoglycans of the implants. Connective Tissue Res. 1991;26:23-6.

\section{Correspondence:}

Bernardo Hochman, MD

Discipline Plastic Surgery/Department of Surgery

São Paulo Federal University

Rua Napoleão de Barros, 715 - $4^{\text {th }}$ floor

04024-900 São Paulo - SP Brazil

Tel: (5511)5082-2133

lydia.dcir@epm.br
Conflict of interest: none Financial source: CAPES (n $\left.{ }^{\circ} 0210165\right)$

Received: January 18, 2005

Review: February 25, 2005

Accepted: March 10, 2005

\section{How to cite this article:}

Hochman B, Vilas Bôas FC, Mariano M, Ferreira LM. Keloid heterograft in the hamster (Mesocricetus auratus) cheek pouch. Acta Cir Bras. [serial online] 2005 May-June;20(3). Available from URL: http://www.scielo.br/acb 